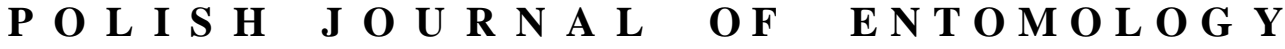

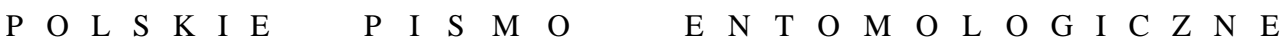

VOL. 83: $71-77$

Lublin

31 March 2014

DOI: $10.2478 /$ pjen-2014-0005

\section{Pastureland copses as habitats for a primeval forest relict: a unique location of the Rosalia Longicorn Rosalia alpina (L.) (Coleoptera: Cerambycidae) in the Polish Carpathians}

\author{
MiChA£ CIACH $^{1}$, JAKUB MichaLCEWICZ ${ }^{2}$ \\ ${ }^{1}$ Department of Zoology and Wildlife Management, Forest Biodiversity Institute, \\ Faculty of Forestry, University of Agriculture, Al. 29 Listopada 46, 31-425 Kraków, \\ Poland, e-mail: michal.ciach@ur.krakow.pl \\ ${ }^{2}$ Department of Forest Protection, Entomology and Forest Climatology, Faculty \\ of Forestry, University of Agriculture, Al. 29 Listopada 46, 31-425 Kraków, Poland, \\ e-mail: j.michalcewicz@ur.krakow.pl
}

\begin{abstract}
The Rosalia longicorn Rosalia alpina is regarded as a primeval forest relict and occurs mainly in old beech woodland in mountain areas. This paper describes a locality of the species in a copse surrounded by pastures, lying in open farmland situated at some distance from woodlands. The larval host plant was Wych Elm Ulmus glabra. The trees at this locality were dying from Dutch elm disease, which is caused by the fungus Ophiostoma sp. It is demonstrated that under favourable circumstances $R$. alpina can also colonise copses in pastureland, a hitherto unknown habitat for this species. At the same time this newly discovered locality may signify a change in the species' habitat preferences. $R$. alpina is under threat, however, from the possible felling of the dead trees by the landowner; conservation measures should therefore include a mechanism for financial compensation in return for not cutting the trees down. This work has shown that copses may be used by endangered saproxylic species. The discovery of a $R$. alpina locality in a pastureland copse gives an indication of the importance of pockets of unmanaged habitat in the farming landscape, which could be contributing to the preservation of populations of rare species.
\end{abstract}

KEY WORDS: Cerambycidae, Rosalia alpina, xylophage, insect, dead wood, farmland, host plant, copse, Dutch elm disease. 


\section{INTRODUCTION}

The Rosalia Longicorn Rosalia alpina (L.) is considered a primeval forest relict (GUTOWSKI 2004). This beetle is trophically associated with Beech Fagus L., although the literature does name other larval food plants (see CiACH \& MichalCEWICZ 2013 and references cited there). In Central Europe the species occurs mostly in old beech woodland in mountain areas (BURAKOWSKI et al. 1990). In Poland, however, R. alpina was recently found in previously unknown habitats - in a forest clearing community at the succession stage containing dominant Wych Elm Ulmus glabra HUDS., and on roadside Ash trees Fraxinus excelsior L. (MichalCEWICZ et al. 2011, MichalCEWICZ \& CIACH 2012). In addition to European Beech Fagus sylvatica L., the only larval food plant of $R$. alpina larvae known until recently in Poland (DOMINIK \& STARZYK 1989, STARZYK 2004b), we now have Wych Elm (CIACH et al. 2007, MichalCEWICZ et al. 2011) and Sycamore Acer pseudoplatanus L. (MichalCEWICZ et al. 2013). It thus emerges from the above that in Poland $R$. alpina is capable of utilising various habitats and different food plants. The present paper describes a locality of this species in a copse among pastures lying in a farmland landscape at some distance from woodland.

\section{METHODS}

The fieldwork was carried out in the Łysa Góra range of the Beskid Niski Mountains in SE Poland. This locality of $R$. alpina was discovered during a methodical search for potential habitats of this species situated well away from woodland complexes. Imagines of Rosalia alpina were searched for visually, sometimes with the aid of binoculars. The characteristic features of the adults' exit holes were used to confirm the feeding of $R$. alpina larvae (see CiACH \& MichALCEWICZ 2013 and references cited there). Fragments of Wych Elm branches from this locality were taken to the laboratory for examination for the presence of Dutch elm disease, caused by fungi from the genus Ophiostoma SYD. et P. SYD., which could be the reason for the trees' moribund state. The laboratory tests involved the micro- and macroscopic analysis of the disease symptoms and the isolation of the fungus (from vessels) on potato dextrose agar (PDA) growth medium. 


\section{RESULTS}

This new locality of Rosalia alpina lies near the village of Myscowa in the commune of Krempna (the exact location is not given for conservation reasons). This is a farming village and the landscape around is dominated by meadows and pastures. The locality is situated on private land, in a copse surrounded by pastures where farm animals are put out to graze. It lies well away from any woodland, $200 \mathrm{~m}$ from the edge of an extensive, closecanopied forest complex (Fig. 1). Located on the edge of a gully, the part of the copse described here consists of Sycamore, Wych Elm, European Beech, Norway Maple Acer platanoides L. and Wild Cherry Cerasus avium (L.) MoENCH. The understorey contains much Hazel Corylus avellana L.

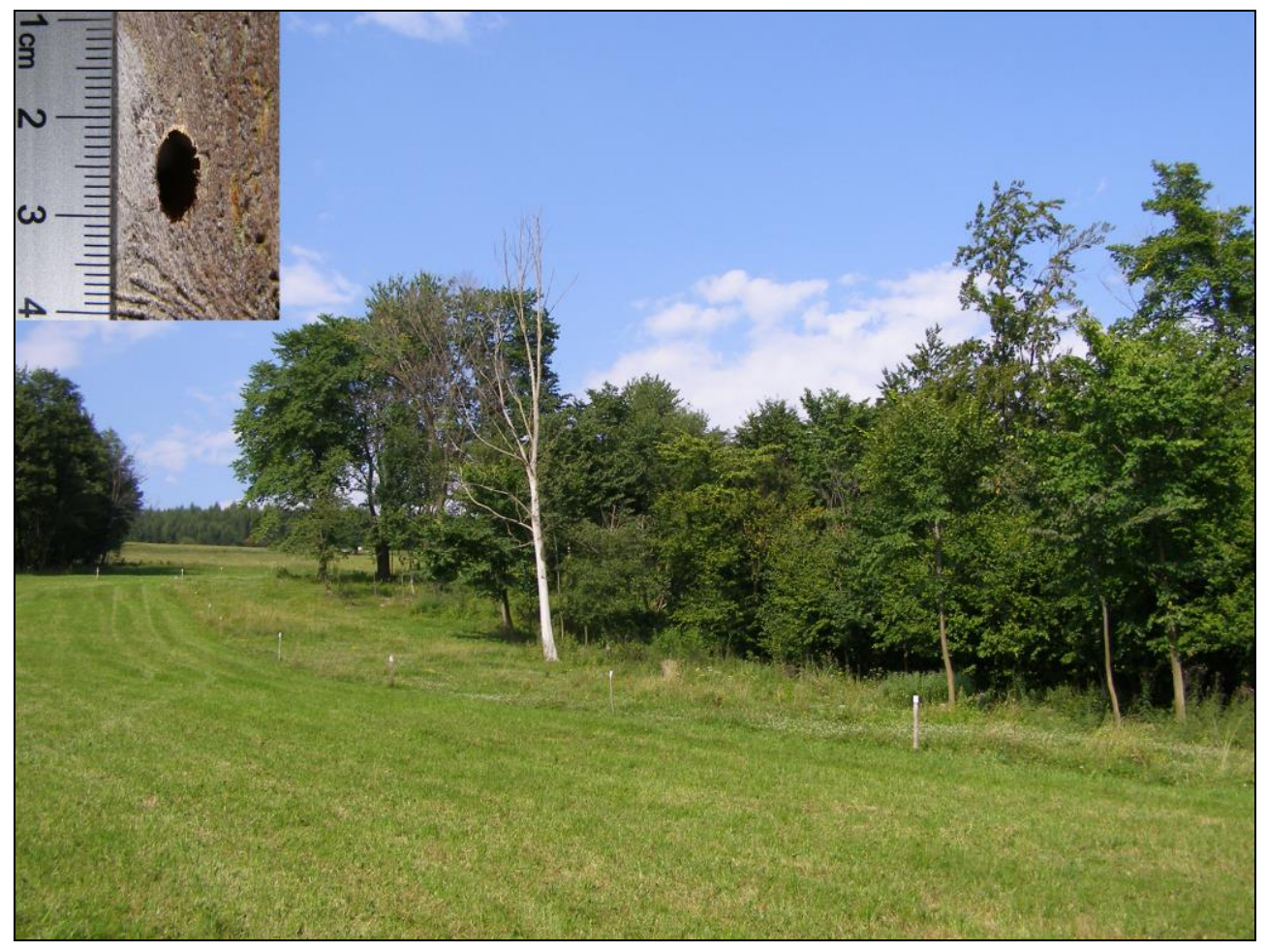

Fig. 1. The locality of the Rosalia Longicorn Rosalia alpina in a pastureland copse near Myscowa and the adult exit hole in the trunk of a dead Wych Elm Ulmus glabra (Beskid Niski Mts, SE Poland; July 2013). Photo by J. MichaLCEWICZ. 
On 14 July 2013 two adult exit holes were found in the trunk of a dead Wych Elm (Fig. 1) and two adult Rosalia alpina beetles were also seen at this locality. Up to five adult beetles were observed at this same locality on 26 July 2013. The actual habitat of $R$. alpina is a stand of 69 Wych Elms covering an area of ca $2500 \mathrm{~m}^{2}$ at the edge of the copse. The elms form a small clump surrounded by farmland, mostly pastures and hay meadows. The mean diameter at breast height (DBH) and mean height of the Wych Elms making up this locality were $19.3 \mathrm{~cm}(\mathrm{SD}=15.1$, range $7-86.5 \mathrm{~cm}, \mathrm{~N}=69)$ and $11.5 \mathrm{~m}(\mathrm{SD}=4.8$, range $5-25.1 \mathrm{~m}, \mathrm{~N}=69)$ respectively. $28 \%$ of the trees in the copse are dead $(\mathrm{N}=69)$. There are also 76 stumps of previously felled trees. The locality lies at an altitude of $445 \mathrm{~m}$ above sea level, and has an SSW exposure and an inclination of $10^{\circ}$. Isolation of the fungus and the disease symptoms of the Wych Elms indicate that these trees are dying of Dutch elm disease.

\section{DISCUSSION}

Copses, i.e. single trees and shrubs or groups of them growing away from woodland and urban areas, which fulfil ecological and aesthetic functions and are sometimes productive, constitute a food resource for various species of insects. They can be utilised by various saproxylic insects, including beetles (GUTOWSKI 2006). Rare species belonging to this group include the Great Capricorn Beetle Cerambyx cerdo L. (STARZYK 2004a), the Hermit Beetle Osmoderma eremita (SCOP.) (SZWAŁKO 2004) and the Red Click-beetle Elater ferrugineus L. (BUCHHOLZ \& OsSOWSKA 2004).

This work has shown that given favourable circumstances Rosalia alpina can also colonise pastureland copses, where suitable conditions for its development can form. The fact that it has colonised a copse surrounded by open farmland is important in the context of what is known so far about this species' habitats (unique, hitherto unknown in Poland) and the rarity of its occurrence. This strictly protected, endangered species was classified as being of very high risk (STARZYK 2004b). Being a priority species, it is listed in Annexes II and IV of the HABITATS DIRECTIVE (1992) and requires active conservation measures (ACT 2004, Regulation 2011). The colonisation of this locality by $R$. alpina may be a consequence of the its migration from its localities in the nearby forest complex (MichalCEWICZ et al. 2011). Moreover, this is well within the beetle's dispersal capabilities (DRAG et al. 2011): the copse is situated 770 and $800 \mathrm{~m}$ from these woodland localities. Dutch elm disease has contributed to the formation of this new locality of $R$. alpina. It would appear that the prevalence of this disease is of fundamental importance to the formation of suitable food resources for this species. 
This newly discovered locality may be a sign of changes taking place in the habitat preferences of Rosalia alpina, in which processes occurring in the forest environment play an important part. Associated with forest management (maintenance of forest stand health, increasing tree density, elimination of grazing) and natural succession, they increase the canopy density and therefore the shading of potential environments where this species can flourish. In consequence, it has been showing an extinction debt since the end of the $19^{\text {th }}$ century. The deterioration of light conditions in woodlands may be potentiating the drainage of the $R$. alpina population in that this is abandoning the forest for sunlit wood piles. The departure of $R$. alpina from the forest, even in combination with a change in food plant, to roadside Ash trees, open riparian woodland and open tree stands on abandoned farmland (CizeK et al. 2009, MichalCEWiCZ et al. 2011, MichaLCEWICZ \& CiACH 2012) is an indicator of the unfavourable temperatures prevailing within close-canopied forests, despite the presence in them of dead wood. The thermophilicity of $R$. alpina and its preference for open-canopied woodland (DRAG et al. 2011, RUSSO et al. 2011) testifies to the strict requirements of this species as regards the insolation of the breeding material.

It is worth mentioning that copses in open terrain may provide natural areas acting as stepping stone habitats or wildlife corridors, which, given the dispersal capabilities of the adult beetles (DRAG et al. 2011), would connect the main patches of Rosalia alpina habitat in this region (the Łysa Góra and Kamień ranges). It may well be that $R$. alpina is making use of copse habitats on a larger spatial scale. Confirmation of this would be of great significance for the conservation of this rare longhorn beetle.

This newly discovered habitat of Rosalia alpina requires conservation. It is endangered in the sense that the landowner could decide to cut down and remove the dead trees. Conservation measures should include a mechanism for compensating landowners for losses they incur by refraining from obtaining timber from localities that currently and potentially provide breeding material for this species. The inference from the above is that habitats need to be created in the future for this species by planting new copses and/or reconstructing existing ones, for example, by allowing dead wood to form and to ensure that adequate levels of insolation reach it.

The discovery of a Rosalia alpina locality in a pastureland copse provides sound evidence in support of the statement that patches of unfarmed habitat in an agricultural landscape are of great significance and could be contributing to the maintenance of populations of rare species.

\section{REFERENCES}

ACт 2004. Act of 16 April 2004 on Nature Conservation. Dziennik Ustaw No. 92, pos. 880. (in Polish) 
Buchiolz L., Ossowska M. 2004. Elater ferrugineus (LinnAeus, 1758), Red Click Beetle. [in:] GŁOWACIŃSKi Z., NOWACKi J. (eds.). Polish Red Book of Animals, Invertebrates. Instytut Ochrony Przyrody PAN, Akademia Rolnicza im. Augusta Cieszkowskiego, Kraków - Poznań: 119-120. (in Polish)

Burakowski B., Mroczkowski M., Stefańska J. 1990. Catalogue of Polish Fauna XXIII, 15. Beetles - Coleoptera. Cerambycidae and Bruchidae. PWN, Warszawa. (in Polish)

Ciach M., Michalcewicz J. 2013. Correlation between selected biometric traits of adult Rosalia alpina (L.) (Coleoptera: Cerambycidae) and size of their exit holes: new perspectives on insect studies? Polish Journal of Ecology 61(2): 349-355.

Ciach M., Michalcewicz J., Fluda M. 2007. The first report on development of Rosalia alpina (LinnAeus, 1758) (Coleoptera: Cerambycidae) in wood of Ulmus L. in Poland. Polish Journal of Entomology 76(2): 101-105.

Cizek L., Schlaghamerský J., BoŘuckÝ J., Hauck D., Helešic J. 2009. Range expansion of an endangered beetle: Alpine Longhorn Rosalia alpina (Coleoptera: Cerambycidae) spreads to the lowlands of Central Europe. Entomologia Fennica 20(3): 200-206.

DOMiniK J., StaRZYK J.R. 1989. Wood protection. Wood-destroying insects. PWRiL, Warszawa. (in Polish)

Drag L., Hauck D., Pokluda P., Zimmermann K., Cizek L. 2011. Demography and dispersal ability of a threatened saproxylic beetle: a mark-recapture study of the Rosalia Longicorn (Rosalia alpina). PLoS ONE 6(6): e21345.

Gutowski J.M. 2004. Longhorn beetles (Cerambycidae). [in:] Bogdanowicz W., Chudzicka E., Pilipiuk I., SkiBiŃSKa E. (eds.). Fauna of Poland - Characteristics and checklist of species. Vol. 1. Muzeum i Instytut Zoologii PAN, Warszawa: 49-53, 73-76. (in Polish)

GuTOwSKI J.M. 2006. Saproxylic beetles. Kosmos 55(1): 53-73. (in Polish)

Habitats DiRective 1992. Council Directive 92/43/EEC of 21 May 1992 on the conservation of natural habitats and of wild fauna and flora. http://ec.europa.eu/environment/nature/legislation/ habitatsdirective (Site visited on 16.03.2012)

Michalcewicz J., Bodziarczyk J., Ciach M. 2013. Development of the rosalia longicorn Rosalia alpina (L.) (Coleoptera: Cerambycidae) in the sycamore maple Acer pseudoplatanus $\mathrm{L}$. - the first report from Poland. Polish Journal of Entomology 82(1): 19-24.

Michalcewicz J., CiACH M. 2012. Rosalia longicorn Rosalia alpina (L.) (Coleoptera: Cerambycidae) uses roadside European ash trees Fraxinus excelsior L. - an unexpected habitat of an endangered species. Polish Journal of Entomology 81(1): 49-56.

Michalcewicz J., Ciach M., BodziarczyK J. 2011. The unknown natural habitat of Rosalia alpina (L.) (Coleoptera: Cerambycidae) and its trophic association with the mountain elm Ulmus glabra in Poland - a change of habitat and host plant. Polish Journal of Entomology 80(1): 23-31.

Regulation 2011. Regulation of the Minister of Environment of $12^{\text {th }}$ October 2011 on the animal species protection. Dziennik Ustaw No. 237 (2011) pos. 1419. (in Polish)

Russo D., Cistrone L., Garonna A. 2011. Habitat selection by the highly endangered long-horned beetle Rosalia alpina in Southern Europe: a multiple spatial scale assessment. Journal of Insect Conservation 15(5): 685-693.

STARzyK J.R. 2004a. Cerambyx cerdo Linnaeus, 1758, Great Capricorn Beetle. [in:] GŁOWACiŃSKI 
Z., NowaCki J. (eds.). Polish Red Book of Animals, Invertebrates. Instytut Ochrony Przyrody PAN, Akademia Rolnicza im. Augusta Cieszkowskiego, Kraków - Poznań: 147-148. (in Polish)

STARZYK J.R. 2004b. Rosalia alpina (LinNAEus, 1758), Rosalia Longicorn. [in:] GŁOWACiŃSKi Z., NOWACKI J. (eds.). Polish Red Book of Animals, Invertebrates. Instytut Ochrony Przyrody PAN, Akademia Rolnicza im. Augusta Cieszkowskiego, Kraków - Poznań: 148-149. (in Polish)

SzwaŁko P. 2004. Osmoderma eremita (Scopoli, 1763), Hermit Beetle. [in:] GŁOWACIŃSKi Z., NowACKI J. (eds.). Polish Red Book of Animals, Invertebrates. Instytut Ochrony Przyrody PAN, Akademia Rolnicza im. Augusta Cieszkowskiego, Kraków - Poznań: 103-104. (in Polish)

Received: 10 September 2013

Accepted: 21 January 2014 